\title{
ANALISIS ADDED VALUE PROGRAM KAWASAN RUMAH PANGAN LESTARI (KRPL) TERHADAP EKONOMI RUMAH TANGGA (STUDI KASUS PADA KELOMPOK WANITA TANI "DEWI SRI" KOTA BATU) \\ Dhaniel Syam ${ }^{1}$ \\ Novitasari Agus Saputri ${ }^{2}$ \\ Aviani Widyastuti ${ }^{3}$
}

Fakultas Ekonomi dan Bisni, Universitas Muhammadiyah Malang ${ }^{1,2,3}$

\begin{abstract}
Abstrak
Tujuan dari penelitian ini adalah menganalisis adanya nilai tambah dari kegiatan kawasan rumah pangan lestari (KRPL) terhadap ekonomi keluarga. Pada dasarnya KRPL yang didukung oleh Dinas Pertanian dan Dinas Ketahanan Pangan Kota Batu ini bertujuan untuk memenuhi kebutuhan pangan dari setiap anggotanya dengan cara menanam tanaman pangan organik sehingga kebutuhan pangan rumah tangga dapat dipenuhi dengan kegiatan tersebut. Metode yang digunaan dari penelitian ini menggunakan metode analisis deskriptif dengan teknik pengumpulan data melalui wawancara terstruktur dan dokumentasi. Hasil penelitian menunjukkan bahwa kegiatan implementasi Kawasan Rumah Pangan Lestari pada kelompok tani wanita Dewi Sri memiliki nilai tambah ekonomi atau economics value added. Value added pada kegiatan ini dapat diukur secara kualitatif maupun kuantitatif. Secara kualitatif dapat terlihat dari adanya aktivitas menjual barang hasil panen oleh anggota kelompok, artinya pada dasarnya tujuan KRPL adalah untuk ketahanan pangan keluarga namun apabila anggota sudah memenuhi segala kebutuhanya dari barang yang ditanamnya maka anggota bebas menjual barang tersebut epada orang lain. Diukur secra kuantitatif dapat dijelaskan pada saat anggota menerima sejumlah pendapatan yan berasal dari selisih pembelian dan penjualan yang dilaksankaan oleh kelompok. Selisih tersebut diakui sebagai pendapatan anggota dan asumsinya anggota dapat meningkatkan jumlah pendapatan keluarga melalui KRPL selain sebagai kegiatan yang memiliki tujuan untuk ketahanan pangan keluarga.
\end{abstract}

Kata Kunci : Value Added, Ekonomi Keluarga, KRPL

\section{PENDAHULUAN}

Pertumbuhan ekonomi di Indonesia cenderung mengalami penurunan dalam beberapa tahun terakhir (PPN, 2016). Hal ini tampak terlihat dari melemahnya permintaan internasional dan melambatnya pertumbuhan investasi. Harga komoditas yang cenderung rendah serta peraturan pemerintah yang tidak pasti menjadi bagian dari pemicu penurunan yang terjadi. Dalam rangka meningkatkan standar kehidapan secara berkelanjutan, tentunya stabilitas ekonomi perlu dipertahankan dan dijaga. Mengingat jumlah penduduk yang tidak sedikit di Indonesia, dalam upaya penjaminan kesejahteraan masyarakat maka diperlukan suatu ruang fiskal yang lebih lebar khususnya peningkatan belanja pemerintah seperti pendidikan, kesehatan, dan juga pengentasan kemiskinan.

Kebutuhan pokok individu cenderung sebagai kebutuhan yang harus dipenuhi demi melangsungkan hidupnya. Adapun kebutuhan pokok tersebut meliputi kebutuhan makan, pakaian dan tempat tinggal. Ketersediaan dan kemampuan individu dalam pemenuhan kebutuhan akan mempengaruhi kelangsungan hidupnya. Indonesia merupakan negara agraris dimana oleh dunia diakui sebagai negara yang mampu menyediakan bahan pangan bagi masyarakatnya. Data menunjukan luas lahan pertanian mencapai 8.114.829 ha (BPS, 2014). Hal tersebut mengindikasikan bahwa dengan luas lahan pertanian yang cukup luas diharapkan Indonesia mampu memenuhi kebutuhan pangan masyarakat secara mandiri tanpa ada ketergantungan kepada Luar Negeri.

Ketimpangan pendapatan pada kenyataannya masih tidak dapat dihindari. Artinya kemiskinan yang terjadi di Indonesia sampai saat ini masih dapat dirasakan dengan jumlah penduduk miskin yang tidak sedikit. Sumber daya alam yang ada di Indonesia sendiri cukup melimpah, akan tetapi kondisi geografis dan transportasi seringkali menjadi salah satu alasan penghambat dalam hal pemanfaatan sumber daya

\footnotetext{
Idhaniel@yahoo.com

${ }^{2}$ novitasariiainta@gmail.com

3 avianiw@gmail.com
} 
dengan maksimal. Kondisi yang sedemikian pada akhirnya justru membawa pemerintah pada kebijakan impor untuk memenuhi kebutuhan masyarakat yang semestinya dengan sumber daya alam yang tersedia mampu memenuhi kebutuhan dalam negeri.

Kebijakan impor bahan pangan atau pertanian akhir-akhir ini menjadi suatu perbincangan yang menarik. Kebijakan impor bahan pangan memang memberikan jaminan ketersediaan. Namun kenyataannya justru menjauhkan Negara Indonesia sebagai negara agragris dari kedaulatan pangan. Perhitungan yang menunjukkan bahwa impor pangan lebih menguntungkan dibandingkan dengan produksi sendiri perlu dilakukan pengkajian kembali. Karena pada kenyataannya istilah menguntungkan tersebut hanya berpihak pada para eksportir saja.

Masa kejayaan petani di Indonesia seiring berjalannya waktu runtuh dikala kaum tani di Indonesia berubah konsep dari bercocok tanam menjadi pembeli seperti yang telah diungkapkan oleh Bugiakso dalam republika.co.id (2016) (diakses tanggal 27 september 2016) sebagai berikut :

“.....Bugiakso menilai awal mula kehancuran kaum tani dan pertanian Indonesia ketika terjadinya perubahan konsep menanam menjadi membeli. Lalu munculnya fakta, kata dia, dari bercocok tanam menjadi kuli yang akhirnya menjadi petani di Indonesia sama artinya menjadi miskin. Dengan fakta yang ada tersebut, ia melihat banyak anak petani yang tidak mau lagi memendam cita-cita menjadi petani. Lalu muncullah logika berpikir bahwa cara untuk tidak terus terjerumus dalam kemiskinan adalah berhenti menjadi petani. "Adakah yang lebih pilu dari mendapati kenyataan seperti ini? Adakah yang lebih ironis dari kenyataan negeri agraris ini?" katanya.

Undang- Undang No. 18 Pasal 60 Tahun 2012 tentang Pangan telah mengamanatkan bahwa Pemerintah dan Pemerintah Daerah berkewajiban mewujudkan penganekaragaman konsumsi pangan untuk memenuhi kebutuhan gizi masyarakat sesuai dengan potensi dan kearifan lokal untuk mewujudkan hidup sehat, aktif dan produktif. Kementerian Pertanian merupakan Lembaga Negara yang membantu Pemerintah dalam mengelola serta mengendalikan ketersediaan pangan Negara. Melalui Badan Ketahanan Pangan Kementrian Pertanian membuat kebijakan- kebijakan terkait dengan ketersediaan pangan. Terkait dengan hal tersebut, Badan Ketahan pangan memiliki tiga kebijakan pangan yaitu peningkatan ketersediaan pangan yang bersumber dari produksi dalam negeri, penguatan distribusi dan peningkatan akses pangan, peningkatan kualitas konsumsi dan keamanan pangan (Lampiran Keputusan Menteri Pertanian No.12/KPTS/KN.210/K/02/2016 Tanggal 17 Februari 2016). Kebijakan yang telah dibuat tentunya akan diimplemtasikan melalui program- program pemerintah.

Peningkatan ketersediaan pangan yang bersumber dari produksi dalam negeri merupakan kebiajakan pertama yang harus segera direalisasikan. Sesuai dengan Peraturan Pemerintah Nomor 22 Tahun 2009 Tentang Kebijakan Percepatan Penganekaragaman Konsumsi Pangan Berbasis Sumber Daya Lokal, maka pemerintah membuat suatu program Percepatan Penganekaragaman Konsumsi Pangan (P2KP) sebagai implementasi dari PP Nomor 22 Tahun 2009 tersebut. Sebagai bentuk implementasi program P2KP maka Pemerintah membuat tiga kegiatan yaitu: (1) Optimalisasi Pemanfaatan Pekarangan melalui konsep Kawasan Rumah Pangan Lestari (KRPL), (2) Model Pengembangan Pangan Pokok Lokal (MP3L), (3) Sosialisasi dan promosi P2KP. Melalui tiga kegiatan ini diharapkan mampu meningkatkan kualitas konsumsi masyarakat dengan memanfaatkan sumber daya yang tersedia dengan pola konsumsi pangan yang baik.

Pelaksanaan Percepatan Penganekaragaman Konsumsi pangan (P2KP) yang dilaksanakan melalui kegiatan KRPL adalah dengan cara optimalisasi pemanfaatan pekarangan rumah melalui upaya pemberdayaan wanita untuk mengoptimalkan pekarangan sebagai sumber pangan dan gizi keluarga. Kegiatan inidapat dilaksanakan dengan menanam beragai aneka tanaman pangan, hortikultura maupun dengan bertenak sebagai upaya untuk menunjag ketersediaan pangan sebagai sumber karohidrat, vitamin, mineral dan protein keluarga.

Wulandari, Darwanto, \& Irham, (2015) melakukan penelitian atas nilai tambah dan kontribusi industri kerajinan bambu (IKB) di sleman guna melihat distribusi pendapatan masyarakat. Hasilnya menunjukkan bahwa pendapatan dari program IKB tersebut mampu memperbaiki distribusi pendapatan rumah tangga pengrajin.

Penelitian serupa juga dilakukan oleh Hasanah, Masyuri, \& Djuwari (2015). Penelitian tersebut membandingkan nilai tambah agroindustry sale pisang berdasarkan pisang raja siam yang digunakan, metode membuat, asal kerekel sale, pengusahanya dan juga factor-faktor yang berpengaruh terhadap produksi sale pisang. Bila dilihat dari ukuran pengusahanya menunjukkan bahwa pengusaha yang membeli kerekel sale mampu menciptakan nilai tambah yang lebih besar dbandingkan dengan membuat kerekel sendiri. 
Asmarantaka (2007) juga melakukan analisis struktur dan perilaku ekonomi rumah tangga petani di desa-desa yang menanam tanaman pangan (padi dan singkong). Hasil penelitian menunjukkan bahwa struktur pendapatan beras terutama berasal dari pertanian, sedangkan desa singkong berasal dari sektor non pertanian. Penggunaan tenaga keluarga untuk mencari nafkah belum memenuhi kriteria Biro Pusat Statistik untuk pekerja fulltime, walaupun telah memenuhi kriteria ketahanan pangan. Di desa beras, investasi (pengeluaran pendidikan dan kesehatan) dan tabungan rumah tangga petani dipengaruhi secara signifikan oleh dan responsif terhadap pendapatan pertanian, sedangkan konsumsi dipengaruhi oleh jumlah anggota keluarga. Di sisi lain, di desa singkong, investasi (pengeluaran pendidikan dan kesehatan) dan penghematan rumah tangga petani dipengaruhi dan responsif terhadap pendapatan non pertanian dan pendapatan total, sedangkan konsumsi juga dipengaruhi oleh pendapatan non pertanian dan jumlah anggota keluarga, meski tidak responsif.

Kota Batu merupakan salah satu contoh daerah yang memiliki kejelian dalam mengelola daerahnya, khususnya dalam mengeksplorasi sumberdaya yang dimilki. Potensi pariwisata Kota Batu yang begitu besar, menunjukkan bahwa dengan pelimpahan wewenang yang juga disertai dengan kejelian dan tentunya semangat dalam mengembangkan daerah maka daerah justru dapat lebih memotivasi dalam pembangunan. Selain pariwisata, potensi pertanian di Kota Batu cukup besar dan secara alami sudah dikenal sebagai kota Agropolitan. Didukung oleh sumberdaya alam yang ada potensi pertanian di Kota Batu terutama potensi hortikultura dapat berkembang dan menjadi sumber penghasilan utama mayoritas masyarakat di Kota Batu.

Apel tetap menjadi icon Kota Batu dan telah diupayakan perbaikan mutu dan nilai tambah sehingga dijadikan beberapa bentuk pangan olahan. Selain itu tanaman sayuran dataran tinggi seperti kentang, kubis, wortel dan sebagainya juga sangat potensial sekali untuk dikembangkan di sebagian besar wilayah Kota Batu. Potensi tanaman bunga juga sangat berkembang dan mendukung pembangunan pariwisata di Kota Batu. Selain tanaman hortikultura tanaman pangan padi palawija juga tetap dibudidayakan di bagian wilayah yang berdataran agak rendah.

Sesuai Visi Kota Batu yaitu "Sentra Pertanian Organik Berbasis Kepariwisataan Internasional" maka Dinas Pertanian dan Kehutanan Kota Batu yang berperan penting dalam perkembangan ekonomi masyarkat khususnya pada bidang pertanian memiliki tanggung jawab penuh untuk mewujudkan visi tersebut. Adapun cara untuk mencapai visi tersebut maka Dinas Pertanian dan Kehutanan Kota Batu memiliki Misi diantaranya adalah meningkatkan SDM pertanian Kota Batu dan meningkatkan agribisnis dan agroindustri berbasis pertanian domestik pedesaan.

Beberapa misi yang telah diuraikan di atas dapat diwujudkan dengan banyak program kegiatan, di antaranya adalah mendukung kegiatan Kawasan Rumah Pangan Lestari (KRPL) yang diselenggarakan oleh Badan Ketahanan Pangan. Kegiatan KRPL merupakan implementasi dari program Percepatan Penganekaragaman Konsumsi Pangan yang dicanangkan oleh Badan Ketahan Pangan dibawah Kementrian Pertanian Republik Indonesia.

Kegiatan KRPL memiliki dasar prinsip yang kuat yaitu pemanfaatan pekarangan yang ramah lingkungan dan dirancang untuk pemenuhan kebutuhan pangan dan gizi keluarga, diversifikasi pangan berbasis sumberdaya lokal, pelestarian tanaman pangan untuk masa depan serta peningkatan pendapatan yang pada akhirnya akan meningkatkan kesejahteraan rumah tangga dan masyarakat (Buku Pedoman Pelaksanaan Percepatan Penganekaragaman Konsumsi Pangan Tahun 2015). Kegiatan KRPL dilaksanakan di setiap Rukun Tetangga maupun Rukun warga disetiap desa atau kelurahan.

Pelaksana program KRPL adalah kelompok tani dalam suatu wilayah yang memiliki prinip yang sama yaitu peningkatan pemenuhan kebutuhan pangan dan gizi keluarga dengan memanfaatkan pekarangan sebagai kawasan pangan lestari. Program KRPL digalakan untuk beberapa kota di Indonesia, salah satunya adalah Kota Batu Jawa Timur. Di Kota Batu beberapa kelompok Tani Wanita menjalankan program KRPL, salah satu adalah Kelompo Tani Wanita Dewi Sri Kelurahan Dadaprejo Kecamatan Junrejo Kota Batu. Program KRPL di keluarkan oleh Badan Ketahanan Pangan Kota Batu dan didukung oleh Dinas Pertanian dan Kehutanan Kota Batu.

Kegiatan kelompok tani wanita dewi sri dalam menjalankan program KRPL adalah penenaman tanaman sayur organik. Jenis tanaman yang ditanam oleh anggota kelompok tani wanita Dewi Sri sangat beragam, disesuaikan dengan kebutuhan pangan anggota kelompok.

Uraian latar belakang di atas membawa peneliti untuk merumuskan suatu pertanyaan penting dalam penelitian ini yaitu (a) Bagaimana implementasi program KRPL di Kota Batu?. (b) Apakah program KRPL mampu membawa nilai tambah terhadap perubahan ekonomi keluarga anggota? 


\section{METODOLOGI PENELITIAN}

Penelitian ini dilakukan pada satu situs penelitian yaitu Kelompok Wanita Tani Dewi Sri yang berlokasi di Kelurahan Dadaprejo Kecamatan Junrejo Kota Batu Jawa Timur dengan obyek penelitiannya adalah Program KRPL (Kawasan Rumah Pangan Lestari). Jenis penelitian yang digunakan adalah jenis penelitian deskriptif kualitatif yang artinya penelitian ini berusha mendeskripsikan suatu gejala, peristiwa dan kejadian saat sekarang denga maksud memperoleh data yang berbentuk kata, kalimat, skema dan gambar. Adapun jenis data yang digunakan adalah data primer yakni data yang diperoleh langsung di lapangan melalui wawancara dan juga data sekunder data yang diperoleh secara tidak langsung atau data yang diperoleh dari sumber-sumber yang relevan.

Penelitian ini didukung dengan metode pengumpulan data wawancara dan dokumentasi. Data primer bersumber dari anggota KRPL Kelompok Wanita Tani Dewi Sri dengan cara wawancara. Di mana wawancara yang dilakukan dengan cara tidak terstruktur sedangkan metode dokumentasi dilakukan dengan mengumpulkan data-data tertulis yang mendukung penelitian. Data yang dikumpulkan adalah data terkait penjualan dan pembelian produk KRPL yang dihasilkan Kelompok Wanita Tani Dewi Sri. Untuk menjawab pertanyaan penelitian digunakan 4 (empat) tahapan analisis menggunakan model Milles \& Huberman (1992) yaitu pertama, dengan melakukan pengumpulan data. Setalah data terkumpul dilanjutkan pada tahap kedua, yakni melakukan reduksi data. Dikarenakan dalam penelitian ini data yang diperoleh memuat informasi yang banyak dan luas, maka proses reduksi data sangat diperlukan. Dimana, dalam mereduksi data berarti yang dilakukan peneliti adalah memilah, memilih, dan juga merangkum hal-hal pokok, fokus pada hal-hal penting, menarik tema dan pola yang sesuai dengan tujuan penelitian.

Langkah ketiga adalah penyajian data yaitu peneliti menyajikan data, yaitu mengemas apa yang ditemukan dalam bentuk teks, table, bagan atau gambar (Creswell, 2015). Dan yang terakhir, menarik kesimpulan. Di dalam penelitian kualitatif penarikan kesimpulan merupakan suatu temuan baru atau sesuatu yang sebelumnya pernah ada. Dari temuan yang diperoleh dapat berbentuk deskripsi suatu objek, bahkan kritisi terhadap temuan yang mungkin sebelumnya masih terlihat samar. Sehingga, harapannya peneliti mampu menguraikan lebih jelas atas temuan tersebut.

\section{HASIL DAN PEMBAHASAN}

Adapun hasil dari penelitian ini berdasarkan model analisis dari Milles \& Huberman (1992) yang menjelaskan 4 tahapan model, yang pertama yaitu melakukan pengumpulan data, kedua mereduksi data, ketiga menyajikan data dan terakhir adalah memberikan kesimpulan.

\section{Tahap Pengumpulan Data}

Kegiatan KRPL (Kawasan Rumah Pangan Lestari) merupakan program pemerintah yang digalakan oleh Kementerian Pertanian dalam mewujudkan ketersediaan sumber pangan secara mandiri. Program KRPL membantu rumah tangga dalam menyediakan kebutuhan pangan keluarga berupa sayuran dan buah. Kelompok wanita Tani Dewi telah berhasil melaksanakan program KRPL sejak 2014. Program KRPL berawal disosialisasikan oleh Dinas Pertanian dan Kehutanan Kota Batu. Selanjutnya Badan Ketahanan Pangan bersama- sama Dinas Pertanian dan Kehutanan Kota Batu berupaya untuk menerapkan program KRPL. Penerapan program KRPL ditunjang oleh bantuan dana dan hibah dari Badan Ketahanan Pangan dan juga Disperta Kota Batu yang bertujuan untuk pelaksanaan dan pengembangan program. Hibah yang diberikan berupa bantuan bibit, saprodi, peralatan pertanian berupa media tanam serta bantuan dana yang digunakan untuk pengembangan hasil pertanian yang dilakukan oleh kelompok. Selain bantuan tersebut,pada tahun 2016 Disperta Kota Batu juga memberikan bantuan berupa pembangunan green house yang digunakan untuk laboratorium yang terletak di Demplot Kelurahan Dadaprejo Kecamatan Junrejo Kota Batu.

Bantuan hibah berupa bibit, saprodi dan media tanam dibagikan kepada semua anggota kelompok. Dana dikelola secara mandiri oleh kelompok selanjutnya dimanfaatkan secara bersama- sama. Pengelolaan dana bantuan diwujudkan dalam bentuk simpan pinjam yang diberikan kepada anggota. Pengelolaan simpan pinjam memang kurang sesuai dengan tujuan KRPL, namun simpan pinjam dikhususkan bagi anggota yang ingin mengembangkan KRPL. Dana ini biasanya dimanfaatkan untuk membayar biaya- biaya yang terkait pengembangan KRPL, misalnya adalah untuk biaya upah untuk pengolahan tanah, biaya dengaHasil penelitian menunjukan bahwa anggota yang mengikuti program KRPL yang diselenggarakan oleh pemerintah dapat menikmati program tersebut. Hasil yang dapat dinikmati oleh anggota diantaranya adalah terpenuhinya kebutuhan pangan keluarga secara mandiri. Setiap anggota KRPL mampu menyediakan sumber kebutuhan pangan berupa buah dan sayur organik secara mandiri. Hasil panen dapat 
dikonsumsi sendiri oleh anggota kelompok, bahkan hasil panen dari anggota berlebih. Hal tersebut dapat terlihat dari adanya penjualan hasil panen kepada masyarakat yang dihimpun dan dikelola oleh kelompok.

Informasi yang diterima menjelaskan bahwa hasil panen tanaman hasil program KRPL selain dikonsumsi oleh anggota kelompok, maka sisa hasil panen dijual kepada masyarakat umum. Hal tersebut dilakukan berdasarkan tingginya permintaan masyarakat akan kebutuhan sayur dan buah organik. Selain itu, penawaran atas sayur dan buah organik masih sedikit, sehingga dengan kegiatan penjualan yang dilakukan oleh kelompok tani wanita ini mampu memenuhi kebutuhan rumah tangga masyarakat sekitar. Tanaman organik yang dijual oleh kelompok tani wanita merupakan tanaman buah dan sayur yang sehat, selain melaksanakan program KRPL sesungguhnya penanaman tanaman organik juga merupakan salah satu visi dan misi Kota batu untuk menuju Kota Wisata Batu Go Organic.

Panen dilakukan tiga kali dalam satu minggu, yaitu hari senin, kamis dan jumat. Panen dilakukan secara mandiri oleh anggota, selanjutnya sisa konsumsi dari anggota dikirim kepada pengurus kelompok untuk dilakukan pengemasan dan dilakukan penjualan. Konsumen dari kelompok wanita tani Dewi Sri beragam, misalnya ibu- ibu rumah tangga, beberapa unit bisnis di Universitas di Kota Malang sampai supermarket yang memang menyediakan buah dan sayur organik. Hasil panen setiap minggunya berubahubah, hal ini terjadi karena tanaman yang siap panen di pekarangan anggota dan juga demplot juga berubahubah tergantung ketersedeiaan di pekarangan.

Produk yang dihasilkan oleh anggota kelompok wanita tani adalah sayur dan buah organik diantaranya yaitu brokoli, sawi pakcoy, bawang merah, seledri, jagung manis, cabai dan sayur organik lainya. Produk dikemas dengan berat masing- masing 250gr dengan harga yang beragam. Setiap produk memiliki harga yang berbeda- beda dan dijual sesuai dengan harga pasar saat itu sehingga harga bisa setiap saat berubah- ubah. Setiap anggota juga akan melakukan penjualan dengan kuantitas yang berbeda- beda pula karena tergantung dari hasil panen di pekarangan mereka. Pada umumnya setiap anggota melakukan penjualan dengan model saving, yaitu dengan mengirimkan hasil panen mereka kepada pengurus untuk dijual secara bersama- sama dengan hasil panen anggota lain, selanjutnya oleh pengurus akan dibukukan produk apa yang dikirim, dengan berat tertentu dan diikuti harga jual pasar yang akan diberlakukan. Proses ini dilakukan cecara berulang- ulang hingga hasil panen mereka terkumpul dan pada akhir periode hasil panen yang telah dibukukan oleh pengurus akan dilaporkan dan dibayarkan kepada anggota.

\section{Reduksi Data}

Tahap reduksi data dilakukan bertujuan untuk memilih dan memilah data yang diperlukan dalam penelitian sehingga penelitian menggunakan data yang sesuai dan mampu menghasilkan kesimpulan yang tidak bias. Data penelitian dalam penelitian ini fokus pada data pembelian dan data penjualan. Data pembelian adalah data yang diperoleh dari aktivitas pembelian yang dilakukan kelompok dari para anggota yang tergabung dalam kelompok tani wanita Dewi Sri. Tujuan dari pembukuan aktivitas pembelian ini adalah agar mempermudah bagi kelompok mengidentifikasi nama- nama anggota yang mengirimkan barang untuk dijual kelompok. Selain untuk mengetahui nama- nama anggota yang mengirimkan barang, data ini juga digunakn sebagai dasar kelompok dalam menentukan berapa jumlah uang yang harus diberikan kepada anggota karena setiap anggota mengirimkan jenis barang dan berat barang yang berbeda- beda.

Berikut ini adalah data pembelian yang dimiliki Kelompok Tani Wanita Dewi Sri beberapa bulan di Tahun 2016 - 2017. Data dapat dilihat di dalam tabel 4.1 berikut ini :

Rekap Pembelian 2016-2017

Tabel 4.1 Data Pembelian

\begin{tabular}{|c|c|c|c|}
\hline No & Tahun & Bulan & Jumlah \\
\hline 1 & 2016 & April & $\begin{array}{l}\mathrm{Rp} \\
146.900\end{array}$ \\
\hline 2 & & Mei & $\begin{array}{l}\mathrm{Rp} \\
138.450\end{array}$ \\
\hline 3 & & Juni & $\begin{array}{l}\mathrm{Rp} \\
130.400\end{array}$ \\
\hline 4 & & Juli & $\begin{array}{l}\mathrm{Rp} \\
113.850\end{array}$ \\
\hline 5 & & Agustus & $\begin{array}{l}\mathrm{Rp} \\
239.120\end{array}$ \\
\hline
\end{tabular}




\begin{tabular}{|c|c|c|c|}
\hline 6 & & September & $\begin{array}{l}\mathrm{Rp} \\
231.500\end{array}$ \\
\hline 7 & & Oktober & $\begin{array}{l}\mathrm{Rp} \\
183.250\end{array}$ \\
\hline 8 & & November & $\begin{array}{l}\mathrm{Rp} \\
207.700\end{array}$ \\
\hline 9 & & Desember & $\begin{array}{l}\mathrm{Rp} \\
60.100\end{array}$ \\
\hline 10 & \multirow[t]{10}{*}{2017} & Januari & $\begin{array}{l}\mathrm{Rp} \\
245.116\end{array}$ \\
\hline 11 & & Februari & $\begin{array}{l}\mathrm{Rp} \\
54.400\end{array}$ \\
\hline 12 & & Maret & $\begin{array}{l}\mathrm{Rp} \\
120.330\end{array}$ \\
\hline 13 & & April & $\begin{array}{l}\mathrm{Rp} \\
42.500\end{array}$ \\
\hline 14 & & Mei & $\begin{array}{l}\mathrm{Rp} \\
95.900\end{array}$ \\
\hline 15 & & Juni & $\begin{array}{l}\mathrm{Rp} \\
88.000\end{array}$ \\
\hline 16 & & Juli & $\begin{array}{l}\mathrm{Rp} \\
154.910\end{array}$ \\
\hline 17 & & Agustus & $\begin{array}{l}\mathrm{Rp} \\
427.495\end{array}$ \\
\hline 18 & & September & $\begin{array}{l}\mathrm{Rp} \\
106.270\end{array}$ \\
\hline 19 & & Oktober & $\begin{array}{l}\mathrm{Rp} \\
93.400\end{array}$ \\
\hline & \multicolumn{2}{|c|}{$\begin{array}{c}\text { TOTAL } \\
\text { KESELURUHAN }\end{array}$} & $\begin{array}{l}\text { Rp } \\
2.879 .591\end{array}$ \\
\hline
\end{tabular}

Sumber : data diolah peneliti

Berdasarkan tabel 4.1 di atas, dapat dilihat bahwa hampir setiap bulan di tahun 2016 dan tahun 2017 ada transaksi pembelian. Adapun di bulan- bulan tertentu tidak ada pembelian dikarenakan pada bulan- bulan tersebut anggota kelompok tidak menjual barang kepada kelompok. Anggota tidak melakukan aktivitas penjualan kepada kelompok dikarenakan hasil panen anggota dikonsumsi sendiri oleh anggota. Sehingga pada bulan terssebut kelompok juga tidak ada aktivitas penjualan.

Pembelian barang hasil panen anggota dikumpulkan menjadi satu, kelompok akan memilah produk barang sejenis untuk dikemas dan selanjutnya dijual kepada konsumen. aktivitas mengumpulkan barang dari anggota ini dilakukan tiga kali dalam satu minggu, yaitu pada hari senin, kamis dan jumat. Produk barang yang dibeli oleh kelompok dari anggota tidak semua sama, ergantng pada saat itu produk barang apa yang siap untuk dibeli kelompok dari anggota karena memang pada dasarnya anggota dapat menjual produk barang setelah kebutuhan konsumsi atas barang tersebut sudah tercukupi.

Data penjualan adalah data yang diperoleh dari aktivitas penjualan yang dilakukan kelompok kepada konsumen yaitu masyarakat umum. Data ini memuat produk barang apa yang dijual dan disertai dengan informasi harga pasar yang berlaku dihari tersebut. Produk barang yang dijual dikelompokan kedalam barang sejenis, sehingga pada saat barang yang dibeli dari anggota memiliki beragam jenis, maka kelompok harus memilah produk barang mana yang sejenis sehingga bisa dikemas menjadi satu produk barang hingga barang siap dijual.

Berikut ini adalah data penjualan yang dimiliki oleh kelompok tani wanita Dewi Sri yang dijelaskan dalam tabel 4.2 berikut ini:

Rekap Penjualan

Tabel 4.2 Data Penjualan

\begin{tabular}{ccccc}
\hline No & Tahun & Bulan & & \multicolumn{2}{c}{ Jumlah } \\
\hline $\mathbf{1}$ & 2016 & April & Rp & 384.000 \\
\hline
\end{tabular}




\begin{tabular}{rrrrr}
\hline $\mathbf{2}$ & Mei & $\mathrm{Rp}$ & 636.000 \\
\hline $\mathbf{3}$ & Juni & $\mathrm{Rp}$ & 353.500 \\
\hline $\mathbf{4}$ & Juli & $\mathrm{Rp}$ & 210.000 \\
\hline $\mathbf{5}$ & Agustus & $\mathrm{Rp}$ & 495.000 \\
\hline $\mathbf{6}$ & September & $\mathrm{Rp}$ & 522.500 \\
\hline $\mathbf{7}$ & Oktober & $\mathrm{Rp}$ & 499.000 \\
\hline $\mathbf{8}$ & November & $\mathrm{Rp}$ & 492.000 \\
\hline $\mathbf{9}$ & Desember & $\mathrm{Rp}$ & 361.000 \\
\hline $\mathbf{1 0}$ & 2017 & Januari & $\mathrm{Rp}$ & 451.000 \\
\hline $\mathbf{1 1}$ & Februari & $\mathrm{Rp}$ & 76.450 \\
\hline $\mathbf{1 2}$ & Maret & $\mathrm{Rp}$ & 167.800 \\
\hline $\mathbf{1 3}$ & April & $\mathrm{Rp}$ & 65.700 \\
\hline $\mathbf{1 4}$ & Mei & $\mathrm{Rp}$ & 88.000 \\
\hline $\mathbf{1 5}$ & Juni & $\mathrm{Rp}$ & 195.000 \\
\hline $\mathbf{1 6}$ & Juli & $\mathrm{Rp}$ & 256.000 \\
\hline $\mathbf{1 7}$ & Agustus & $\mathrm{Rp}$ & 895.000 \\
\hline $\mathbf{1 8}$ & September & $\mathrm{Rp}$ & 281.000 \\
\hline $\mathbf{1 9}$ & Oktober & $\mathrm{Rp}$ & 127.000 \\
\hline & Total Keseluruhan & $\mathbf{R p}$ & $\mathbf{6 . 5 5 5 . 9 5 0}$ \\
\hline
\end{tabular}

Sumber : data diolah peneliti

Tabel 4.2 menjelaskan tentang data penjualan yang dilakukan oleh kelompok. Aktivitas penjualan sepenuhnya dikelola oleh kelompok dengan memperhatikan jumlah pembelian produk barang yang teah dilakukan dari anggota. Data penjualan menunjukan data keseluruhan jumlah penjualan setiap bulan. Harga yang ditetapkan dalam proses penjualan ini adalah harga pasar yang berlaku pada saat itu. Harga pasar yang digunakan merupakan harga yang belaku umum, namun kelompok juga tetap memperhatikan margin laba yang diinginkan, artinya walaupun aktivitas penjualan berdasarkan harga pasar namun kelompok tetap menjual produk barang sesuai dengan margin yang diinginkan sehingga kelompok dan anggota dapat menerima laba sesuai yang telah ditetapkan.

\section{Penyajian Data}

Data pembelian dan data penjualan yang telah dikumpulkan akan dianalisis dan dikaitkan dengan analisis added value. Analisis added value adalah analisis yang fokus pada upaya perusahaan dalam menciptakan nilai perusahaan dalam menilai kinerja keuangan perusahaan yang dapat diukur melalui struktur modal yang ada. Tujuan analisis added value menjelaskan tentang upaya penciptaan nilai perusahaan yang lebih riil. Penelitian ini menggunakan analisis added value untuk mengetahui nilai tambah atas program yang telah dilaksanakan oleh pemerintah, yaitu program KRPL. Program KRPL dilaksankan dibeberapa kota di seluruh wilayah Indonesia.

Program KRPL dilaksanakan di Kota Batu sejak tahun 2014, termasuk kelompok tani wanita Dewi Sri telah melaksanakan program KRPL sejak tahun 2014. Awal mula pelaksanaan KRPL di KWT Dewi Sri bertujuan untuk meningkatkan ketahanan pangan keluarga. Bantuan dari pemerintah berupa dana hibah dan bantuan hibah lain misalkan berupa bibit, saprodi serta media tanam yang dibagikan kepada semua kelompok dan dikelola secara mandiri oleh masing- masing kelompok. Bantuan dana dikelola kelompok tani wanita Dewi Sri secara mandiri dalam bentuk aktivitas simpan pinjam. Tunjuan dari aktivitas ini adalah untuk memfasilitasi anggota dalam mengembangkan KRPL yang telah dijalankan. Adapun manfaat yang bisa diambil dari aktivitas simpan pinjam ini adalah pada saat anggota ingin mengembangkan usaha maka mereka memiliki kesempatan untuk meminjam dana hibah yang dikelola oleh kelompok. Selain itu, aktivitas simpan pinjam juga dapat dimanfaatkan oleh anggota untuk menyimpan dana hasil pengelolaan produk barang yang telah dihasilkan oleh anggota. 
Bantuan lain yang diterima anggota adalah bantuan berupa bibit, saprodi dan media tanam yang dapat digunakan dan dikembangkan oleh anggota. Bantuan tersebut diterima oleh semua anggota yang keseluruhanya didapatkan secara gratis. Artinya pada saat anggota ingin meningkatkan ketahanan pangan keluarga maka pemerintah memberikan fasilitas tersebut. Selain meningkatkan ketahanan pangan keluarga, hasil panen berupa buah dan sayur bisa dikelola oleh anggota dengan cara dijual ke masyarakat umum. Kegiatan ini dikelola langsung oleh kelompok, sehingga aktivitas jual beli tidak dilakukan langsung oelh anggota. Model jual beli yang dilakukan oleh kelompok tani wanita Dewi Sri dilakukan degan model saving, artinya produk barang yang akan dijual dikumpulkan terlebih dahulu oleh kelompok selanjutnya dikelola kelompok dan akhirnya dijual ke konsumen.

Data pembelian yang dilakukan oleh kelompok dapat dilihat di tabel 4.1, sedangkan data penjualan yang dilakukan oleh kelompok dapat dilihat dari tabel 4.2. Selisih antara pembelian dan penjualan diakui dihitung dan diakumulasikan selama satu bulan. Selisih ini diakui sebagai pendapatan anggota kelompok tani wanita Dewi Sri. Selisih inilah yang diakui sebagai added value dari kegiatan KRPL. Diakui sebagai added value karena pada dsarnya tujuan dari KRPL hanya untuk memperkuat ketahanan pangan keluarga, namun karena ketahanan pangan keluarga sudah terpenuhi maka anggota bisa menjual produk barang tersebut kepada masyarakat. Selain itu, modal yang didapatkan oleh anggota untuk menanam tanaman pangan hingga menjual produk barang tersebut berasal dari hibah maka tidak ada lagi modal yang harus dikeluarkan oleh anggota untuk melaksanakan kegiatan ini. Asumsinya modal maupun biaya modal dari kegiatan ini adalah nol, sehingga selisih pembelian dan penjualan yang dilaksankan oleh kelompok diakui sebagai pendapatan anggota dan bisa juga diakui sebgai added value. Selisih antara pembelian dan penjualan atau bisa disebut sebagai pendapatan anggota dapat dilihat di tabel 4.3 di bawah ini:

Tabel 4.3. Tabel Pendapatan

\begin{tabular}{|c|c|c|c|}
\hline NO & TAHUN & BULAN & SELISIH \\
\hline 1 & 2016 & April & $\mathrm{Rp} \quad 237.100$ \\
\hline 2 & & Mei & $\mathrm{Rp} \quad 497.550$ \\
\hline 3 & & Juni & $\mathrm{Rp} \quad 223.100$ \\
\hline 4 & & Juli & 96.150 \\
\hline 5 & & Agustus & $\mathrm{Rp} \quad 255.880$ \\
\hline 6 & & September & Rp $\quad 291.000$ \\
\hline 7 & & Oktober & $\mathrm{Rp} \quad 315.750$ \\
\hline 8 & & November & $\mathrm{Rp} \quad 284.300$ \\
\hline 9 & & Desember & $\mathrm{Rp} \quad 300.900$ \\
\hline 10 & 2017 & Januari & Rp $\quad 205.884$ \\
\hline 11 & & Februari & 22.050 \\
\hline 12 & & Maret & 47.470 \\
\hline 13 & & April & 23.200 \\
\hline 14 & & Mei & $\mathrm{Rp} \quad(7.900)$ \\
\hline 15 & & Juni & Rp 107.000 \\
\hline 16 & & Juli & $\mathrm{Rp} \quad 101.090$ \\
\hline 17 & & Agustus & $\mathrm{Rp} \quad 467.505$ \\
\hline 18 & & September & $\mathrm{Rp} \quad 174.730$ \\
\hline 19 & & Oktober & $\mathrm{Rp} \quad 33.600$ \\
\hline \multicolumn{3}{|c|}{ TOTAL PENDAPATAN } & Rp3.676.359 \\
\hline
\end{tabular}

Sumber : data diolah peneliti

Kesimpulan dari penelitian ini adalah adanya economics value added pada program KRPL yang diselenggarakan oleh pemerintah yang bertujun untuk menciptakan ketahanan pangan yang dimulai dari keluarga dengan cara memanfaatkan lahan pekarangan sebagai lahan tanam berbagai jenis tanaman buah dan sayur organik. Adapun economics value added yang dirasakan oleh anggota kelompok tani wanita 
Dewi Sri dapat dijelaskan secara kualitatif maupun kuantitatif. Secara kualitatif dapat dijelaskan melalui kemampuan anggota dalam melaksanakan aktivitas menjual barang hasil panen kepada masyarakat sekitar. Hal tersebut disebut sebagai value added karena pada dasarnya KRPL memiliki tujuan awal hanya untuk menciptakan ketahanan pangan keluarga artinya pada saat anggota kelompok dapat menjual hasil panenya asumsinya kebutuhan konsumsi mereka sudah terpenuhi.

Adapun economics value added secra kuantitatif dapat dilihat melalui jumlah pendapatan yang diterima oleh masing- masing anggota sebagai nilai tambah pendapatan keluarga. Artinya, sebelum anggota tergabung dalam akelompok dan sebelum anggota melaksankaan program KRPL anggota kelompok wanita tani tidak memiliki pendapatan tabahan karena rata- rata mereka adalah ibu rumah tangga. Namun dengan adanya kegiatan ini, anggota memiliki tambahan pendapatan dimana tambahan pendapatan ini mampu membantu memperkuat ekonomi keluarga.

\section{KESIMPULAN DAN SARAN \\ Kesimpulan}

Penelitian ini dapat dismpulkan bahwa:

a. Kegiaatan KRPL memiliki economics value added berupa aktivitas menjual hasil panen berupa buah dan sayur organik kepada masyarakat. Dikatakan memiliki economics value added karena pada dasarnya program KRPL memiliki tujuan awal untuk meningkatkan ketahanan pangan Nasional melalui keluarga yaitu ppemanfaatan lahan pekarangan untuk tempat penanaman sejumlah tanaman buah dan sayur untuk dikonsumsi keluarga. Naun pada kenyataanya, pada saat kebutuhan konsumsi keluarga sudah terpenuhi maka anggota dapat menjualnya kepada masyarakat sekitar.

b. Kegiatan KRPL memiliki economics value added jika dilihat secara kuantitatif. Artinya, anggota kelompok wanita tani Dewi Sri memiliki pendapatan tambahan dari hasil penjualan barang hasil panen mereka. Pendapatan tambahan ini diakui sebagai economics value added karena pada saat anggota belum melaksanakan program KRPL mereka tidak memiliki pendapatan karena pada umumnya mereka berprofesi sebagai ibu rumah tangga. Pendapatan tambahan yang diterima oleh anggota kelompok wanita tani diakui mampu memperkuat ekonomi keluarga sehingga dapat Implikasi meningkatkan taraf hidup mereka.

Penelitian ini memberikan implikasi bahwa kebijakan yang disusun oleh Kemeterian Pertanian melalui Badan Ketahanan Pangan dalam mendukung Pemerintah untuk menciptakan ketahanan pangan mandiri telah berhasil. Selain mampu menciptakan ketahanan pangan mandiri yang dimulai dari keluarga telah berhasil, program ini juga berimplikasi pada ekonomi keluarga anggota kelompok wanita tani. Implikasinya adalah dengan menjalankan program KRPL ekonomi keluarga semakin kuat sehingga mampu meningkatkan taraf hidup anggota kelompok wanita menjadi lebih baik.

\section{Keterbatasan}

Penelitian ini memiliki keterbatasan pada data. Adapaun keterbatasan datanya adalah masih dilakukan penelitian di satu kelompok wanita tani di Kota Batu saja, meskipun program KRPL sudah dijalankan secara meluas hampir diseluruh Kabupaten dan Kota di seluruh Indonesia. Maka dari itu untuk penelitian selanjutnya dapat dilakukan penelitian sejenis namun dengan objek yang lebih luas sehingga informasi hasil penelitian dapat dimanfaatkan secara umum dan luas.

\section{UCAPAN TERIMA KASIH}

Terimakasih kepada semua pihak yang berpartisipasi dalam penelitian ini yang tidak dapat disebutkan satu- persatu oleh peniliti. Ucapan terimaksih juga peneliti sampaikan khusus kepada Pusat Pengembangan Ekonomi, Bisnis dan Kewirausahaan (PPEBK) Fakultas Ekonomi dan Bisnis Universitas Muhammadiyah Malang yang telah memberikan kesempatan kepada peneliti untuk melaksanakan penelitian serta memberikan fasilitas pendaanaan untuk proses penelitian. Semoga kesempatan yang diberikan kepada peneliti bermanfaat khususnya bagi peneliti untuk mengembangkan ilmu melalui penelitian. 


\section{REFERENSI}

Asmarantaka, R. W. (2007). Analisis Ekonomi Rumah Tangga Petani Tanaman Pangan di Profinsi Lampung. Jurnal Agribisnis Dan Ekonomi Pertanian, 1(1), 1-18.

Creswell, J. W. (2015). Penelitian Kualitatif dan Desain Riset : Memilih di antara Lima Pendekatan (3rd ed.). Pustaka Pelajar.

Hasanah, U., Masyuri, \& Djuwari. (2015). Analisis Nilai Tambah Agroindustri Sale Pisang di Kabupaten Kebumen. Ilmu Pertanian, 18(3), 141-149.

Hayami, Y, et al. (1987). Agricultural Marketing and Processing in Upland Java. A Perspective from A Sunda Village. Bogor: CGPRT Centre.

Ismail, A. I. (2007). Teologi Kemiskinan. Www.republika.co.id.

Kementrian Pertanian Republik Indonesia. (2015). Buku Pedoman Pelaksanaan Percepatan Penganekaragaman Konsumsi Pangan Tahun 2015. Jakarta

Manullang. (1990). Dasar-dasar Manajemen. Jakarta: Ghalia Indonesia.

Milles, M. ., \& Huberman, A. M. (1992). Analisis Data Kualitatif. Jakarta : Universitas Indonesia.

PPN. (2016). Perekonomian Indonesia Tahun 2016: Prospek dan Kebiajakan.

Republika_online. (2016). Kebijakan Impor Pangan Dinilai Merusak Pertanian Indonesia.

Singh, I., Squire, L., \& Strauss, J. (1986). Agricultural Household Models: Extensions, Applications and Policy. The John Hopkins University Press.

Soeharjo. (1991). Konsep dan Ruang Lingkup Agroindustri dalam Kumpulan Makalah Seminar Agribisnis. Bogor: Buku I. Jurusan Ilmu-ilmu Sosial Ekonomi Pertanian. Fakultas Pertananian IPB.

Sundaya, Y., \& Muhardi. (2011). Perilaku Ekonomi Rumah Tangga Petani Miskin Tanaman Pangan di Jawa barat: Analisis dan Simulasi Kebijakan. MIMBAR, XXVII(1), 57-66.

Wulandari, N. T., Darwanto, D. H., \& Irham. (2015). Analisis Nilai Tambah dan Kontribusi Industri Kerajinan Bambu pada Distribusi Pendapatan Masyarakat di Kabupaten Sleman. Agro Ekonomi, 26(2), 192-205. 